The following is a pre-publication version of

Andrews, P., Ryve, A., Hemmi, K. \& Sayers, J. (2014) PISA, TIMSS and Finnish mathematics

teaching: An enigma in search of an explanation, Educational Studies in Mathematics, 87(1), pp 726

DOI: $10.1007 / \mathrm{s} 10649-014-9545-3$

Page numbers will not match those of the published version 


\title{
PISA, TIMSS and Finnish mathematics teaching: An enigma in search of an explanation1. Introduction
}

\author{
Paul Andrews ${ }^{\mathrm{a}}$, Andreas Ryve ${ }^{\mathrm{b}}$, Kirsti Hemmi ${ }^{\mathrm{b}}$ and Judy Sayers ${ }^{\mathrm{a}}$ \\ a Stockholm University, b Mälardalen Högskola
}

\begin{abstract}
Finnish students' success on all three content domains of each of the four cycles of the OECD's Programme for International Student Assessment (PISA) has created much international interest. It has also prompted Finnish academics to offer systemic explanations typically linked to the structural qualities of Finnish schooling and teacher education. Less well-known has been the modest mathematics performance of Finnish grade 8 students on the two TIMSS on which Finland has participated, which, when compared with its PISA successes, has created something of an enigma. In this paper we attempt to shed light on this enigma through analyses of Finnish mathematics classroom practice that draw on two extant data sets - interviews with Finnish teacher educators and video-recordings of sequences of lessons taught on standard topics. Due to the international interest in Finnish PISA success, the analyses focus primarily on the resonance between classroom practice and the mathematical literacy component of the PISA assessment framework (PAF). The analyses indicate that Finnish mathematics didactics are more likely to explain the modest TIMSS achievements than PISA successes and allude to several factors thought to be unique to the Finns, which, unrelated to mathematics teaching practices, may be contributory to the repeated Finnish PISA successes. Some implications for policy-borrowing are discussed.
\end{abstract}

\section{Keywords}

Over the last few years several systematic reviews have examined the complex relationship between teacher practice and learner achievement; see, for example, Ingvarson, Beavis, Bishop, Peck \& Elsworth (2004) in Australia and Hiebert \& Grouws (2007) in the US. A typical review of this form, conducted in New Zealand, identified ten principles that underpin pedagogical practices shown to facilitate students' mathematical competence and dispositions (Anthony and Walshaw, 2009). Among these principles, in addition to ensuring an appropriate teacher knowledge base, are the importance of building on students' thinking, facilitating mathematical communication, encouraging the development of mathematical language, employing worthwhile mathematical tasks, making appropriate mathematical connections, assessing formatively, and selecting appropriate tools and representations.

However, while we allude to such frameworks in this paper, we do not draw extensively on them. We do, however, end by asking questions about the extent to which they acknowledge the culturally situated nature of mathematics teaching and learning. Indeed, we suggest that students' learning of mathematics is not independent of the cultures, and therefore the curricula, in which they are raised; the nature and ambitions of the schools they attend; the experience, competence and expectations of their teachers; the aspirations espoused at home, and their own and their friends' goals and inclinations. Matters such as these are particularly important when interpreting the results of large scale international tests of achievement. For example, to what extent is a country's success on a particular test due to teacher competence, societal factors whose influence may exceed teacher effects, or a combination of such matters? It would be unfortunate were governments to spend large amounts of public money seeking solutions to internal educational problems in the practices of countries selected on the basis of test results of uncertain provenance.

Finland, much lauded for its repeated PISA successes, may be one such country, and this is the theme of this paper. However, our aim is not to contribute to the debate about teaching 
quality and student learning, although it is an issue to which we return later, but to caution those minded to engage in policy-borrowing against uncritically assuming that PISA success may be attributable to pedagogical quality.

\section{Framing our interest in Finland}

Since 2000 the OECD has undertaken, every three years, a multinational assessment of how well "education systems prepare students for real-life situations" (OECD, 2009, p. 9). Each cycle has assessed 15 year-old students' literacy, mathematical literacy and scientific literacy competences, each focused on the application of subject knowledge to authentic or real-world situations (Adams, 2003). The outcomes of these assessments, despite limitations concerning the form of PISA test items in relation to students' curricular experiences (Prais, 2003; Shiel, Perkins, Close \& Oldham, 2007) have been viewed increasingly as benchmarks against which educational policies and practices have been evaluated. From this perspective Finland (table 1) has created such interest that envoys from all around the world have visited Helsinki to uncover the story behind its success (Laukkanen, 2008), and many Finnish commentators have proposed explanations, discussed below, for this success.

\begin{tabular}{l|llll|}
\multicolumn{1}{c}{} & 2000 & 2003 & 2006 & 2009 \\
\cline { 2 - 5 } Literacy & 1 & 1 & 2 & 3 \\
Mathematical literacy & 4 & 2 & 2 & 6 \\
Scientific literacy & 3 & 1 & 1 & 2 \\
Participating systems & 32 & 41 & 57 & 65
\end{tabular}

Table 1: The ranks of the Finnish scores for each of the three assessed domains over the four completed PISA cycles.

However, a factor, which many commentators seem not to have acknowledged, has been the relatively modest performance of Finnish grade 8 students on the mathematics component of the two TIMSS on which Finland has participated. Indeed, on both TIMSS 1999 and 2011 (Mullis et al, 2000, 2012), Finland trailed by a significant margin the Pacific Rim states that were its peers on all PISA assessments. Moreover, on both occasions the Finnish score was a consequence of relatively low scores on geometry and algebra compensated by higher scores on number, data analysis and measure. Such shortcomings have prompted Finnish mathematicians to suggest that Finnish PISA success may have been at the cost of the mathematical knowledge and skills necessary for higher study of the subject (Astala et al., 2006; Martio, 2009), reflecting what may have been a "Pyrrhic victory" (Tarvainen and Kivelä, 2006, p10).

This juxtaposition of Finnish PISA success and TIMSS shortcomings has created something of an enigma. What is happening in Finnish mathematics classrooms to produce such disparate outcomes? In this paper we examine this enigma through analyses of two serendipitously available data sets that afford insight into the relationship between Finnish PISA success and Finnish mathematics classroom practice - we focus on PISA because of the international interest shown in Finland's success and the fact that Finland has participated in all PISA assessments but only two of the five TIMSS. The first data set comprises sequences of videotaped lessons taught on standard topics by teachers construed locally as effective, while the second comprises interviews undertaken with Finnish mathematics teacher educators. As the analyses unfold, it should become apparent that the Finnish mathematics education enigma is more profound than that indicated by a comparison of PISA and TIMSS results alone. Before then we discuss how the Finns, and by implication external observers, 
typically construe Finnish PISA success. In so doing, we observe that didactical analyses are generally missing from these commentaries.

\section{Perspectives on Finnish PISA success}

According to McKinsey and Company (2007) successful educational systems share three key characteristics. They persuade the right individuals to become teachers; they enable those individuals to become effective practitioners; they ensure the best possible conditions for student learning. In the following, by drawing solely on research reported by Finns, we examine Finnish perspectives on these characteristics.

\subsection{Persuading the right people to become teachers}

In Finland only the most talented become teachers (Simola, 2005; Tuovinen, 2008), with only one in five teacher education applicants being successful (Laukkanen, 2008; Niemi \& JakkuSihvonen, 2006). Teaching is a popular career choice, not least because Finnish teachers operate within a culture of trust (Sahlberg, 2011; Välijärvi, 2004) that extends from the top to the bottom (Sahlberg, 2007). Finnish teachers, who enjoy high public esteem (Simola, 2005), are considered professionals who know what is best for their students (Aho et al., 2006).

\subsection{Teacher education in Finland}

Finnish teachers are well qualified and professionally committed to their own and their students' development (Sahlberg, 2007; Tuovinen, 2008; Välijärvi, 2004). For several decades a master's degree, to ensure an appropriately qualified workforce (Niemi, 2012), has been necessary for teaching in comprehensive schools (Antikainen, 2006; Laukkanen, 2008; Niemi \& Jakku-Sihvonen, 2006) and has been seen by teachers as enhancing their professional status (Jyrhämä et al., 2008). Undertaken in eight Finnish universities (Krokfors et al., 2011), and located in the theory of education rather than craft-practice (Westbury et al., 2005), Finnish teacher education aims to facilitate students' research-warranted solutions to pedagogical problems alongside the development of formal academic research skills (Sahlberg, 2011; Toom et al., 2010; Välijärvi, 2004).

\subsection{Conditions for learning in Finland}

The systemic equity underpinning Finnish education policy is manifested in the wellestablished comprehensive school system (Sahlberg, 2011) and its compulsory nine year curriculum (Aho et al., 2006). Intended to provide education to age 16, a typical comprehensive school is small, local to the student, well-equipped (Lie, Linnakylä \& Roe, 2003) and sufficiently funded for it to provide free school meals for all (Laukkanen, 2008). Students, who not grouped by ability (Antikainen, 2006; Halinen \& Järvinen, 2008; Reinikainen, 2012), are taught in small classes in schools typically construed as learning and caring communities (Aho et al., 2006; Sahlberg, 2007). So well regarded is the comprehensive school that despite the right to choose alternatives parents continue to choose their local school (Poikolainen, 2012) and, unlike those in other Nordic countries, remain positive about education policy irrespective of the politics of the party in power (Fladmoe, 2011).

Finland invests substantially in special educational needs support, particularly during the primary years (Hausstätter \& Takala, 2011). It not only identifies a high proportion of its students - three and a half times the OECD average - as having special educational needs but addresses their needs in class (Vislie, 2003). This integrated provision requires no formal statement of need, begins when difficulties arise (Savolainen 2009), and, particularly in the primary years, is generally focused on pupils' mother tongue and mathematical skills 
(Hausstätter \& Takala, 2011; Kivirauma \& Ruoho 2007). In promoting inclusion it has reduced the stigma of special needs education (Halinen \& Järvinen 2008).

\subsection{Other factors}

Finland is culturally homogeneous (Hannula 2007; Itkonen \& Jahnukainen 2007), a factor generally conducive to educational achievement (Välijärvi et al. 2002). Admittedly, there are Swedish- and Sami-speaking minorities, accounting for around six per cent of the population, but these are taught in mother tongue schools under exactly the same conditions as Finnishspeakers. Finland has experienced relatively little immigration in comparison with other OECD nations (Itkonen \& Jahnukainen 2007), "commonly considered to be one of the reasons for Finnish success” (Reinikainen 2012, p. 13).

Finally, some internal commentators have suggested that understanding Finnish educational success requires an awareness of the role of education in Finnish society (Antikainen 2005). For example, the Finnish identity, stemming from centuries of Swedish and Russian colonialism (Niemi, 2012), is thought to reflect a mind-set closer to those of Korea and Japan than other European (Simola, 2005). The Finns have fought over many centuries for the legitimacy of their mother tongue, not least because the Lutheran church expected its congregation to read the Bible in their own language. Consequently, the Finns have acquired a collective appreciation for education in general and Finnish literature in particular (Halinen \& Järvinen 2008), to the extent that the Finnish library network is among the world's densest, with Finns borrowing more books than anyone else (Sahlberg, 2007).

In sum, the Finns attribute PISA success to a multiplicity of factors related to societal expectations concerning the preparation and professionalism of teachers and a collective acceptance that educational achievement should not be impeded by social inequity. However, such enviable systemic characteristics are unlikely to ensure repeated PISA successes independently of what occurs in classrooms. Interestingly, little is known about the nature of Finnish mathematics classrooms, although, despite government initiatives over the last thirty years (Kupari, 2004), available evidence suggests that Finnish mathematics teaching has barely changed from the traditional practices that dominated the first half of the twentieth century (Carlgren et al., 2006; Norris et al., 1996), particularly with respect to problem solving (Pehkonen, 2009). In this paper, while mindful of its disappointing TIMSS achievements, we examine the relationship between classroom practice and Finland's PISA successes.

\section{The PISA assessment of mathematical competence}

PISA examines the extent to which 15 year-old students "are prepared to meet the challenges of today's societies" (OECD, 2003, p. 9). With respect to mathematics, the explicit focus has been on problems that move "beyond the kinds of situations and problems typically encountered in school classrooms" towards situations people face when going about their daily lives and which necessitate the application of mathematical skills in less structured contexts, where directions are not necessarily clear, and which require "decisions about what knowledge may be relevant, and how it might usefully be applied” (OECD, 2003, p.24). That is, PISA focuses "on the capacity of students to put mathematical knowledge into functional use in a multitude of different situations in varied, reflective and insight based ways" (Schleicher, 2007, p. 351). A key underpinning has been the concept of mathematical literacy, which has been consistently defined as

"an individual's capacity to identify and understand the role that mathematics plays in the world, to make well-founded judgements and to use and engage with 
mathematics in ways that meet the needs of that individual's life as a constructive, concerned and reflective citizen” (OECD 2003, p. 24).

The PISA assessment framework (hereafter labelled PAF) exploited eight mathematical competences derived from the Danish KOM (Kompetencer og matematiklæring) project (OECD 2003, p. 40), arranged in three hierarchical clusters: reproduction, connection and reflection. Reproduction cluster competences allow students to solve routine problems found in the typical mathematics classroom. Connections cluster competencies enable students to solve problems that "are not simply routine, but still involve familiar, or quasi-familiar, settings" (OECD 2003, p. 44). Finally, reflections cluster competences allow students "to plan solution strategies and implement them in problem settings that contain more elements and may be more "original" (or unfamiliar) than those in the connections cluster" (OECD 2003, p. 47). Details of the three competency clusters, against which our analyses are framed, can be seen in table 2. Importantly, those OECD reports that include data on the proportion of students achieving each competency level - and precise figures cannot be discerned due to their being reported graphically - indicate that typically more than three-quarters of Finnish students demonstrate connections level competence, while around a quarter show reflection level competence.

\section{Methods}

As indicated above, in this paper we examine the relationship between Finnish mathematics classroom practice and the PAF-related opportunities students receive. To do so we draw on two unrelated data sets. Neither was collected with PAF-related analyses in mind, although both proved amenable to them and yielded important insights with regard to the Finnish PISA enigma. The first derived from a video study of mathematics teaching undertaken in England, Finland, Flanders, Hungary and Spain. Focused on how four teachers in each country, selected against local criteria of quality, typically present mathematics to their students, sequences of four or five lessons were captured on the teaching of percentages to grades 5 or 6 , polygons to grades 5 or 6 , equations to grades 7 or 8 and finally, polygons again to grades 7 or 8 . Sequences were filmed to reduce the possibility of showpiece lessons and topics were agreed cross-nationally to facilitate comparative analyses. Tripod-mounted cameras were placed discretely at the side or rear of project classrooms and videographers instructed to capture all teacher utterances and, where possible, whatever was written on the board. Teachers wore wireless microphones, while an additional static microphone captured as much whole class student talk as possible. With respect to this paper, all four teachers were working in partnership with the same mathematics teacher education department at the project university. The first two videotapes in each sequence were transcribed and translated into English by English-speaking colleagues at the respective home universities. This enabled the production of subtitled videos that colleagues from all countries could view and analyse. Full details of data collection can be seen in Andrews (2007). The accuracy of the transcripts was checked by Finnish graduate students at the first author's institution. These subtitled videos were then viewed several times by the first and fourth authors to obtain a 'feel' for how the lessons played out before further viewings focused on identifying teacher utterances and actions likely to provide opportunities for students to acquire PAF-related competences. During this process lesson transcripts were iteratively annotated to record our emergent and discursively produced understanding of project lessons.

The second data set derived from a recent interview study of Finnish and Swedish teacher educators' perspectives on the development of prospective teachers' mathematical knowledge for teaching (Ryve, Hemmi \& Börjesson, 2011). The Finnish component comprised two, ninety minute, focus group interviews, each structured by "a few broad questions about 


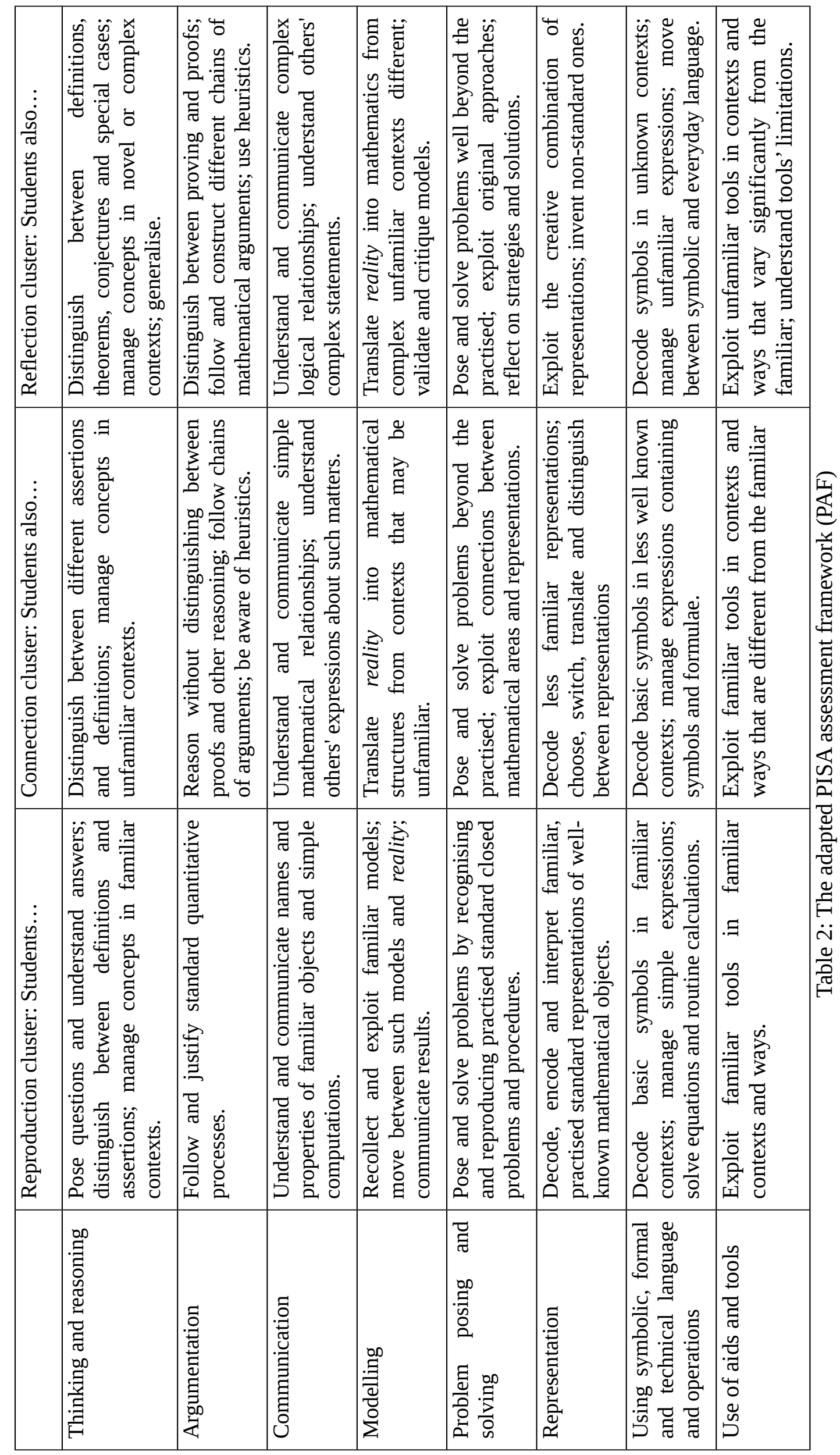


teacher education and knowledge for teaching mathematics” (Ryve et al., p. 4). In arranging the interviews, a known teacher educator at each university was invited to invite a small team of colleagues for group interview. In the Finnish context this yielded two groups, one from each of two well-regarded universities. Both groups comprised colleagues with doctorates in mathematics or mathematics education as well as extensive experience of school-based teacher education work. Thus, while we cannot assume that each group was representative we can assume it was appropriately qualified to discuss Finnish mathematics teacher education. Interviews, which were conducted by the second and third authors, were transcribed in full and translations from Finnish into English were undertaken by a professional translator. These were then compared with the originals by the third author, who is fluent in English, Finnish and Swedish, before making any necessary changes. Analysis involved a two-person constant comparison process (Strauss and Corbin, 1998) in that the second and third authors independently read and re-read the transcripts as a precursor to identifying categories that were then tested on previously read elements of the transcripts. On completion of these independent analyses the two researchers met to discuss and reconcile their accounts. The results presented here derive from that process. The analyses identified a range of issues pertinent to this paper, including "prospective teachers' pre-knowledge, university courses in mathematics, ways of knowing mathematics, (and) the mathematical knowledge of practicing teachers” (Ryve et al., 2011, p.4).

In closing this section we remind the reader that the two data sets, neither of which was gathered with a PISA-related analysis in mind, were obtained independently. We are aware of the limitations of small samples with respect to inferences about general populations but several factors indicate that our participants are unlikely to be unrepresentative of Finnish conceptions of best practice within the domains of teacher education and classroom teaching respectively. Firstly, with respect to the teacher educators' data, there are only eight universities involved in Finnish teacher education (Krokfors et al., 2011), and two wellregarded institutions are represented in this paper. Thus, we feel confident in the authority of the teacher educators' voice. Secondly, the classroom teachers were working in partnership with their local teacher education department, which was based in a different university from those of the teacher educator sample. This, too, is well-regarded, having been nominated as a Centre of Excellence in Mathematics Teacher Education by the Higher Education Evaluation Council. Moreover, in addition to being construed locally as effective, project teachers would have had "to prove they are competent to work with trainee teachers" (Sahlberg, 2011, p. 36). All four were experienced with between 12 and 30 years' service and had remained in close contact with the same teacher education department since graduating from it. Thus, we feel confident that the teachers, three males in their thirties and one female in her fifties, can be considered as reflecting Finnish expectations of teacher expertise.

\section{Results}

\subsection{The observed lessons}

In the following each of the four lesson sequences is discussed in relation to PAF expectations. All four teachers exhibited behaviours commensurate with the majority of the eight PAF competences. However, while there was frequent evidence of reproduction level competences, connection level competences were rare and reflection level competences unseen. Of course, as with any essentially qualitative analysis, there will be subjectivities in respect of the data selected to illustrate the issues under scrutiny, and we acknowledge that others examining the same data may make different choices. That being said, our focus throughout was on identifying episodes that reflected our emergent view of teachers' typical PAF-related behaviours. 


\subsubsection{Antti and the teaching of linear equations}

Antti began his sequence by writing slowly in capitals, Definition: An equation is two expressions denoted as being of equal magnitude. He then wrote six statements, which were publicly examined. The first, the number 5 , led to the following:

Antti Is example $a$ an equation? Think about the definition... Joonas?

Joonas No. Because there is only one expression.

Antti Yes. There is only one expression, 5, which is only a number.

There are elements within this episode - reminding students to focus on the definition and Joonas' explanation - interpretable as evidence of Antti's encouraging mathematical reasoning. However, throughout his lesson sequence, Antti never invited students to explain or justify a contribution; Joonas' voluntary justification was an atypical occurrence and indicated, at least for Antti's practice, that PAF-related reasoning opportunities were uncommon.

In the following episode, Antti asserted that equations can be always true, conditionally true or false, and returned to the six statements discussed earlier. When asked whether $5+3=7$ was true or false, Salla replied that it was false, to which Antti commented, yes, it is always false; we use the term identically false equation. He then attended to $x^{2}=8$, asking, what should $x$ be to make $x$ squared equals eight true? After some prompting Joonas volunteered the square root of eight, to which Antti responded, yes, if $x$ is the square root of eight, this is true. So, this equation is a conditional equation. This equation is true, when $x$ is the square root of eight.

The above was interesting for at least three reasons. Firstly, with respect to both examples, Antti exploited familiar and unproblematic symbols within novel contexts; actions resonant with students' acquisition of connections cluster competences. Secondly, with respect to the square root of eight he did not discuss the existence of both positive and negative values. Thirdly, his reaction to both Salla's and Joonas' responses, was the same; he repeated their answers. In Salla's case he added a comment concerning identically false equations and in Joonas' a comment about conditional equations, but in neither case did he offer or elicit clarification as to the meaning of his additional comments. This practice of neither seeking nor offering clarification appeared to be a regular feature not only of Antti's but also his colleagues' practice.

\subsubsection{Katja and the teaching of geometry}

At the start of her second lesson on twin circles Katja invited students to mark two points at the centre of the page with a space between of about 6 centimetres. She did the same on the board, labelling her points $\mathrm{K}_{1}$ and $\mathrm{K}_{2}$, before adding that the next step is to draw twin circles, with centres $K_{1}$ and $K_{2}$ and radius 4 centimetres. Simultaneously she wrote, in capitals, the heading and the instructions, which her students copied unbidden. While her students constructed their circles, something they had done the previous lesson, Katja did the same, very slowly and precisely. After which the following ensued:

Katja Colour the points of intersection with one colour. So, look for the points of the twin circles' intersections. Is that clear? Someone who has got the idea could come to the board to work it out. Could you come to mark it, Sauli?

Sauli I don't know how to do it.

Katja You don't? That is why we do it. That is why we are writing it down; so that it would not stay unclear to anyone. 
Next she invited Ilja to mark the intersections on the board, which he did. Katja accepted his offering, Yes. There you go. Draw clean crosses to it that we can all see them. Yes, good, good! Thank you. Following this students were asked to construct, with the same centres, circles with radii five centimetres and to mark the intersections. While her students worked Katja wrote more notes in capitals before constructing her own circles. On this occasion Simo was invited to mark the intersections, which he did, receiving the comment, Yes, exactly, good, thank you. Finally, Katja invited suggestions for the radii of a third pair of circles. Someone volunteered $3 \mathrm{~cm}$, which, smiling, Katja accepted. Soon several students noticed that there were no obvious intersections:
Katja There are complaints that there are no intersections. Why is this? Ilja?
Ilja The circles are too small.
Katja Yes, you could say that. The circles are too small, yes, they are, but compared to what, Mari?
Mari When they are too far away from each other.
Katja OK. When is this problem impossible; when do they not intersect? Lauri?
Lauri When the distance between the centres is longer than the distance of the two radii.
Katja Yes, because the distance between $\mathrm{K}_{1}$ and $\mathrm{K}_{2}$ is longer than twice the radius.

Finally, students constructed a third pair of circles. The episode, which lasted nearly fifteen minutes, afforded several PAF-related opportunities. Firstly, the task offered opportunities for students to engage with definitions and concepts in familiar contexts. Secondly, the incident concerning circles of radius three presented an opportunity for students to engage publicly in, and therefore communicate, the reasoning necessary for the inadequacy of such radii. However, this, too, was a familiar context. Thirdly, Katja encouraged students to use familiar notation, including the subscripts given the two circles' centres. Thus, in this opening exchange was evidence of several reproduction level competences.

There were elements of Katja's behaviour worthy of discussion beyond the PAF. Firstly, Katja consistently acted in a way that allowed students either to work unsupported - they were not obliged to attend to her as they constructed their own circles - or to have their efforts scaffolded by her undertaking the same constructions in silence at the board. Secondly, her slow and very deliberate use of capitals highlighted the implicit expectation that students should make detailed notes. Indeed, this was made explicit when Sauli announced he was unable to identify the intersections and Katja responded that is why we are writing it down; so that it would not stay unclear to anyone. Finally, the question that initiated the discussion of the inadequacy of a radius of three was the only occasion in which any of project teacher asked, why?

\subsubsection{Sami and the teaching of percentages}

Sami began his first lesson by asking, what do we mean by the word percent? Aku replied, one hundredth, after which Sami wrote slowly and in silence, Prosentti (=sadasosa) ${ }^{1}$, before asserting that there are three ways to denote one hundredth. Write these in your notebook; write them in an equation form. After about a minute Salla, having been invited to the board, wrote without hesitation but very slowly, $1 / 100=1 \%=0,01$. Sami thanked her before asking for examples of one hundredth from everyday life. Part of the conversation went as follows
Liisa
The circumference of the earth compared with the circumference of the sun
Sami Yes. Simo?
Simo One hundred percent fat.

\footnotetext{
${ }^{1}$ Percent (=hundredth)
} 
Sami Yes, but it can also be one percent fat. Leena?

Leena I have not actually seen one hundredth, but I have seen percentages in election results.

Sami Yes.

It could be argued that Salla's tripartite equation represented an implicit definition. Also, acknowledging her confident manner, it seems likely that her equation was familiar, implying a reproduction cluster perspective on both communication and representation. Interestingly, Sami's reactions to students' responses appeared ambiguous. For example, when thanking Salla for her equation he neither offered nor sought further comment. His identical reaction, yes, to Liisa's and Leena's responses, particularly as Liisa' contribution was opaque and Leena' was clear, left an observer wondering what he intended his students to infer from the exchanges as, in both cases, his utterances were followed by a change of direction unrelated to the contributions made. It is possible that Sami was relating percentages explicitly to realworld phenomena and, in so doing, addressing the PAF's aim of facilitating

"an individual's capacity to identify and understand the role that mathematics plays in the world, to make well-founded judgements and to use and engage with mathematics in ways that meet the needs of that individual's life as a constructive, concerned and reflective citizen” (OECD 2003, p. 24).

However, the extent to which this was achieved is unknown, as the contexts introduced were not pursued beyond what is reported above. Therefore, for an observer and acknowledging Anthony and Walshaw's (2009) framework, a number of questions seem pertinent. Was Leena's allusion to election results clear to her peers? Did Simo's introduction of fat content have any meaning without reference to a context? Also, having asked for examples of hundredths, why did Sami allow the discussion to veer to percentages?

Later that lesson, Sami drew a circle on the board, told the class it represented a cake, and shaded half:

Sami What percentage is the shaded part of this cake? Hanna?

Hanna Fifty (Sami wrote 50\% = on the board next to the diagram)

Sami Yes. And in fractions in the simplest possible form? Simo?

Simo One half (Sami wrote $1 / 2=$ next to the $50 \%$ already written)

Sami Could you construct a decimal from this percentage? Albert?

Albert Zero point five.

Sami Yes. At this stage it is good, Albert, that you said zero point five. It is quite correct. But in order to get a logical connection between this and this (pointing to other two representations), could you express that decimal number with accuracy to hundredths?

Albert Fifty.

Sami Yes. It is worthwhile noting that it helps your thinking tremendously if you recognise that this percentage, which is a whole number, is the same as the first two decimals in a decimal fraction. This 50 , when we change it into a decimal number, appears as two decimals. It is one to one always.

Sami sketched another circle, shaded a quarter, and repeated the process. Quickly the equation $25 \%=1 / 4=0,25$ emerged. This process was repeated several times.

In terms of the PAF the above highlights a focus on different representations of the same numbers and the decoding of basic symbols, albeit at levels of familiarity commensurate with reproduction perspectives. In addition, there were occasions whereby reasoning and argumentation were implicitly addressed, although, as with his colleagues, Sami neither 
offered nor sought clarification, as with his assertion of the rule, write the decimal to an accuracy of one hundredth as this will give a one-to-one correspondence to the percentage.

\subsubsection{Janne and the teaching of polygons}

During his second lesson on polygons Janne invited students to label the vertices of a diagram before asking them to count the number of triangles contained within it. Disagreement emerged as to the correct number, with students offering everything between 5 and 9 inclusive. Janne invited a vote and declared I think eight is the right number, before announcing that our triangles have names..., using those, could we check the number of names there are. Let's not check and just move on. The next task was completed similarly with Janne saying, after another vote to agree the correct answer, let's not check because it would take an eternity to write them all on the board.

In respect of the PAF, Janne appeared to present opportunities for students to solve problems beyond the rehearsed and exploit connections between representations. However, the use of labels to facilitate the identification of geometrical objects, not least because students were exploiting tools, decoding symbols and communicating in familiar ways, barely took them beyond reproduction level competences. More importantly, Janne's actions, which were typical of those observed throughout his sequence of lessons, seemed designed to promote confusion. For example, why encourage vertex labelling as a tool for counting triangles if he intended to ignore it? What did he intend students to infer from his justification by consensus?

In summary, while there was clearly more than a little resonance between teachers' observed practice and PAF-related expectations, particularly at the level of reproduction cluster competences, the evidence for connections cluster competences was limited. There was no evidence of practice commensurate with reflections cluster competences. While the literature has highlighted earlier concerns with Finnish mathematics teaching, none had examined it against the PAF, so this analysis is a first. Importantly, we now draw on the results of our second analysis and consider Finnish teacher educators' perspectives on Finnish mathematics classrooms and whether evidence for PAF-related success can be found there.

\subsection{The teacher educators' interviews}

With respect to the PAF, two themes emerged from the interviews. The first concerned the objective of teacher education, which Jari indicated was to educate teachers into agents of change. Such perspectives, indicating that teachers should have the competence necessary for equipping students with the knowledge and skills necessary for addressing whatever problems they face, whether in school or beyond, resonate well with the broader problem solving ambitions of the PAF. Expanding on the theme, Raija commented that,

In early primary school this means that we develop pupils' thinking. That we provide those tools, in this case, when it concerns early primary school, it means... concrete tools by which one could test one's own thinking and then, through a variety of experiments, create more conceptual reasoning and, so to say, model more encompassing rules. This change, therefore, includes moving away from a 'counting pedagogy', where a certain rule is expressed in a book... that activates little but surface aspects of the brain.

Her advocacy of concrete tools in relation to the development of students' thinking and reasoning alludes not only to the significance of reasoning and argumentation as key goals of the teacher education process but also, in relation to the use of aids and tools, a didactic ambition closer to the reflection cluster competences than reproduction. Meanwhile, her desire to move beyond a counting pedagogy and her belief about the importance of activating 
more than just superficial cognitive skills can be construed as reflecting ambitions beyond reproduction cluster competences. In similar vein Matti commented that not only should students be at the centre of the learning experience but that teachers should trust them, let them try themselves, the teacher should not, too quickly, tell them how things are. He later added that, misdoing, trying, and creativity are the most important conditions for learning. Such perspectives, as with those pertaining to agents of change, fall within the broad aims of the PAF and, implicitly, problem solving related goals.

The second theme concerned teacher educators' experiences of Finnish mathematics teaching, which reflected something different from the agents of change ambitions. Jari, unconvinced that mathematics teaching in ordinary schools had changed much, was unsure that there was research on the matter. His perspective, having recently watched some videotaped lessons, was one of such boring mechanical teaching, while Raija commented that it (boring mechanical teaching) is connected to a much wider problem; where does their (the new teachers') enthusiasm disappear? Both conjectured that newly qualified teachers (NQTs) became enculturated into their professional contexts in ways that undermine initial enthusiasms. Raija observed that something in this mechanism prevents them from using the knowledge that has produced joy; what is it? ... Are their colleagues that dreadful that they, sort of, rebuke everything? Jari added that when they are working in their classrooms their colleagues shouldn't affect them; I do not understand what's there. He continued:

During the 80s, when I led in-service education, it felt as if teachers were very enthusiastic participants. I taught problem solving, games and other activities ... But after a few years, I met these teachers and asked them about their work with problem solving. They explained that there is too little time for it, no materials, and the pupils are against it. They seemed to have had a million excuses for not working with it.

Both Jari and Raija present a picture of teachers, once enthusiastic, who had lost that enthusiasm. They indicate not only that problem solving is essentially absent from the student experience but also, in relation to other PAF-related competences, acknowledge reluctantly a mechanical teaching unlikely to shift students' competences beyond familiar and wellpractised sets of mathematical skills.

Others appeared less pessimistic. Heikki, for example, indicated that the methodological skilfulness of mathematics teachers is pretty good, although one should always strive towards being better, adding that he had been in many schools and thought that the situation was quite good. In related vein, Matti spoke about those teachers who undertake in-service course and remain keen to learn something new. He said,

I am also engaged in in-service courses ... the most pleasant (teachers) are those who have been working some years and are still enthusiastic... they will learn something new and do something despite a certain threshold. There are also teachers who have been working for a long time and want to renew themselves, so there is such willingness and desire.

However, Heikki, Matti and Marja expressed concerns about NQTs' ability to manage aspects of their roles, particularly with respect to students perceived as talented and the demands of didactical differentiation. Marja commented that, in such circumstances, NQTs may experience doubts about their own mathematical competence, believing that their own resources are not enough and therefore (they) quickly realise that this (adhering closely to the curriculum materials) is safe and that no one blames them. In this respect, Matti offered a pertinent observation; 
When you follow the instructions in the textbook ... you can manage everything and your employer has to pay your salary and no one could blame you as the test results become OK. Put in different words; you have achieved the minimum requirements.

Interestingly, despite Heikki's positive perspective on classroom practice and Matti's belief in the enthusiasm of serving teachers, these teacher educators also expressed concerns about NQTs. Such anxieties, leading to a reliance on the textbook and an avoidance of more challenging mathematics, implied an acceptance of the minimum requirement and, in PAF terms, the sacrifice of the problem solving tasks supportive of reflections level competences.

In sum, while teacher educators' perspectives on Finnish mathematics classroom practice ranged from positive to negative, there were two areas of agreements. Firstly, albeit for different reasons, NQTs frequently fell into habits unlikely to support higher level PAF competences. Secondly, teacher educators saw their roles as agents of change promoting such higher level competences.

\section{Discussion}

In this paper we have highlighted what seems to be a mismatch between the much envied PISA-related achievements of Finland on the one hand and the evidence of classroom observations and teacher educator interviews on the other. Moreover, returning to Anthony and Walshaw's (2009) ten principles of effective teaching, and acknowledging that our analyses were framed by the PAF, neither data set indicated evidence of, for example, teachers building on students' thinking, facilitating mathematical communication or assessing formatively. Interestingly, it could be argued that all four lesson sequences incorporated evidence of teachers encouraging the development of mathematical language, employing worthwhile mathematical tasks, making appropriate mathematical connections, and selecting appropriate tools and representations. However, whether such didactical strategies were managed in ways that would facilitate learning in the manner envisaged by Anthony and Walshaw (2009) is unlikely. Thus, the practices of project teachers and the negative views on Finnish classroom teaching espoused by the teacher educators seemed more in accord with the modest performance of Finnish students on TIMSS than their successes on PISA. In other words, the evidence presented above suggests that assumptions, typically made by policymakers and promoted by the world's press, associating PISA success with pedagogical quality seem misguided. Therefore, if Finnish classroom interactions are unlikely to explain Finnish PISA success, what is? In the following, drawing on indications embedded in our data and our reading of the available literature, we speculate a little and, in so doing, present what we believe are interesting and important lines of potential inquiry.

Firstly, as reflected in Katja's comment, that is why we are writing it down; so that it would not stay unclear to anyone, students were encouraged implicitly and explicitly to make notes, which teachers facilitated in similar ways. They modelled solutions, as in Katja's working through problems contemporaneously with her students or Sami's encouragement of students to write percentage equations on the board. Both forms of modelling comprised public contributions written in silence with no teacher comment. Moreover, three of the four teachers always wrote in capital letters, which seemed to slow the pace at which they wrote, leaving students time to copy and read.

Secondly, there were indications that students were expected to discuss mathematics at home. For example, during his first lesson, after discussing the results of a test completed the previous week, Antti instructed students to return your paper tomorrow with a signature showing your parents know how the test went. More significantly, during his second lesson, Janne instructed students to mark three arbitrary points and connect them with straight lines. 
Joona, having placed his points in a straight line, was unable to identify a shape. Janne insisted that Joona should work out why this was the case, which led to the following;

Joona I can't make it out.

Janne Then you'll just have to think about it at home with Mum and Dad.

Such episodes suggest an expectation that parents systematically support their children's mathematical learning, an implication supported by earlier findings that most Finnish teacher education students had not only received help with mathematics from their parents but also that the family encouraged positive attitudes towards the subject (Hannula et al., 2007). Such inter-generational behaviour has been highlighted by evidence showing the positive benefits on children's learning of high quality dynamic cultural capital; that is, the higher the quality of the cultural interactions and communication between children and their parents the better their learning (Tramonte and Willms, 2010).

However, the above are speculative and there may be other cultural explanations. For example, participation in Finnish cultural life necessitates demonstrable reading competence (Välijärvi et al, 2002; Linnakylä, 2002). Thus, it is not surprising to find that Finnish students, who are invariably born of literate parents, have a higher and more successful engagement with reading than students elsewhere (Välijärvi et al, 2002). Moreover, the correlation between Finnish students' reading competence and scientific literacy, as measured by PISA, has been shown to be as high as 0.83 (Kjaernsli \& Molander (2003), while other studies have shown high correlations between Finnish students' reading skills and mathematics achievement (Vilenius-Tuohimaa et al., 2008; Korhonen et al., 2012). In other words, it is possible that Finns excel on language-based tests of mathematical competence like PISA not because they are particularly mathematically competent - their TIMSS scores suggest they are not - but because they are competent and enthusiastic readers.

With respect to our evaluation of Finnish classroom interactions, the above alludes to two important methodological questions. Firstly, Korea has been one of the most successful systems on both TIMSS and PISA. Indeed, the performance of Korean students, across both forms of assessment, has never been outside the top four on all nine reported iterations. However, from the perspective of mathematics classroom practice, Xu and Clarke (2013) describe Korean classroom interactions, not dissimilar to those we describe above, of minimal public discussion, low-level student input and teachers offering limited explanatory support. Such interactions, whether Finnish or Korean, would be construed as inadequate against the pedagogical quality frameworks discussed in the introduction. In other words, we are drawn to ask, are frameworks of effective classroom interaction, typically developed in, and resonant with the reform objectives of, Anglophone countries, appropriate for the analysis of practice in countries culturally distinct from the Anglophone? In this respect, Clarke (2013) has argued strongly that the authors of such frameworks, typically ignoring issues of cultural relativity, assume that what research has shown to be effective in one cultural context will have similar efficacy in another. Secondly, it is not just a question of whether or not such frameworks are appropriate, but about the robustness of the relation between classroom interaction and student performance. Our study not only confirms that the relation between classroom interaction and student learning is complicated but leads us to ask; are we, the mathematics education research community, overestimating the influence of classroom interaction on students' learning?

In closing the reader is reminded that we began by suggesting that Finnish performance on PISA, when viewed against the evidence of our, albeit limited, classroom observations and teacher educator interviews is an enigma. Indeed, our data, derived from teachers construed locally as effective and teacher educators from respected universities, are more likely to 
explain Finland's modest grade 8 TIMSS performance than its well-publicised and repeated PISA successes. The enigma is compounded by a comparison of the PISA results of the Swedish-speaking minority with those of the Finnish-speaking majority. Comprising around 6 per cent of the Finnish population, the Swedish-speaking community, against a variety of measures, is more economically powerful than the Finnish-speaking community (Karhunen and Keloharju, 2001; Keloharju et al., 2012). Therefore it would seem reasonable to expect this group to perform at least as well as the Finnish-speaking community, particularly as the systemic investment in schools is independent of the language group to which a school belongs (Kupiainen et al., 2009). Indeed, recent studies have highlighted the impact of parental assets on children's educational attainment (Huang et al., 2010; Kim and Sherraden, 2011), but, interestingly, this seems not to be the case in Finland, where the Swedishspeaking community's PISA 2009 mathematics score was significantly lower than that of the Finnish-speaking community (Hautamäki et al., 2008; Niemi \& Metsämuuronen, 2010).

Finally, Finland's education system, founded on principles of equality and inclusion, has, with respect to PISA, yielded the smallest between school variation (Halinen \& Järvinen, 2008; Reinikainen, 2012; Schleicher, 2009). Such a system, in which all schools perform equally well, would appear to be the envy of the world and warrant Hausstätter \& Takala's (2011, p. 272) assertion that not only is the Finnish school "the best school in the world, but also... the best school 'for all' in the world". However, our data suggest that despite such systemic strengths and the rhetoric underpinning teacher education, Finnish PISA success may not be a consequence of the quality of classroom interactions but a complex and partially understood interaction of curriculum and culture. Moreover, despite its enviable PISA-related between-school variation, Finland had among the highest within-school variation with respect to students' mathematics (PISA 2003), science (PISA, 2009) and reading (PISA, 2009), further highlighting the potential disparity between Finnish classroom practice and educational achievement as measured by PISA. Finnish education, its success and (relative) TIMSS failures, is an enigma in search of explanation and confirms an earlier observation that "high attainment may be much more closely linked to cultural values than to specific mathematics teaching practices” (Askew et al., 2010, p. 12).

\section{Acknowledgements}

The research reported in this paper was made possible by grants from the European Union, Socrates Action 6.1 programme (2002-5048) and the Swedish Research Council (2007-3961).

References

Adams, R. J. (2003). Response to 'Cautions on OECD's recent educational survey (PISA). Oxford Review of Education, 29(3), 377-389.

Aho, E., Pitkänen, K., \& Sahlberg, P. (2006). Policy development and reform principles of basic and secondary education in Finland since 1968. Washington: The World Bank.

Andrews, P. (2007). Negotiating meaning in cross-national studies of mathematics teaching: Kissing frogs to find princes. Comparative Education, 43 (4), 489-509.

Anthony, G., \& Walshaw, M. (2009). Characteristics of effective teaching of mathematics: A view from the west. Journal of Mathematics Education, 2(2), 147-164.

Antikainen, A. (2005). Introduction: The construction of a learning society. In A. Antikainen (Ed.), Transforming a learning society: The case of Finland (pp.5-21). Berne: Peter Lang.

Antikainen, A. (2006). In search of the Nordic model in education. Scandinavian Journal of Educational Research, 50(3), 229-243. 
Askew, M., Hodgen, J., Hossain, S., \& Bretscher, N. (2010). Values and variables: Mathematics education in high-performing countries. London: Nuffield Foundation.

Astala, K., Kivelä, S. K., Koskela, P., Martio, O., Näätänen, M., \& Tarvainen, K. (2006). The PISA survey tells only a partial truth of Finnish children's mathematical skills. Matilde, 29, 9.

Carlgren, I., Klette, K., Mýrdal, S., Schnack, K. \& Simola, A. (2006). Changes in Nordic teaching practices: From individualised teaching to the teaching of individuals. Scandinavian Journal of Educational Research, 50, 301-326.

Clarke, D. (2013). Contingent conceptions of accomplished practice: The cultural specificity of discourse in and about the mathematics classroom. ZDM - The International Journal on Mathematics Education, In press. doi: 10.1007/s11858-012-0452-8

Fladmoe, A. (2012). The nature of public opinion on education in Norway, Sweden and Finland - measuring the degree of political polarization at the mass level. Scandinavian Journal of Educational Research, 56(5), 457-479.

Halinen, I., \& Järvinen, R. (2008). Towards inclusive education: the case of Finland. Prospects, 38(1), 77-97.

Hannula, M. (2007). Finnish research on affect in mathematics: Blended theories, mixed methods and some findings. ZDM, 39(3), 197-203.

Hannula, M., Kaasila, R., Pehkonen, E., \& Laine, A. (2007). Elementary education students' memories of mathematics in family context. In J. Woo, H. Lew, K. Park \& D. Seo (Eds.), Proceedings of the 31st Conference of the International Group for the Psychology of Mathematics Education (Vol. 3, pp. 1-8). Seoul.

Hausstätter, R., \& Takala, M. (2011). Can special education make a difference? Exploring the differences of special educational systems between Finland and Norway in relation to the PISA results. Scandinavian Journal of Disability Research, 13(4), 271-281.

Hautamäki, J., Laaksonen, S., \& Scheinin, P. (2008). Level and balance of achievement. In J. Hautamäki, E. Harjunen, Airi Hautamäki, T. Karjalainen, S. Kupiainen, S. Laaksonen, J. Lavonen, E. Pehkonen, P. Rantanen \& P. Scheinin (Eds.), PISA 2006 Finland - analyses, reflections and explanations (pp. 36-49). Helsinki: Ministry of Education.

Hiebert, J., \& Grouws, D. (2007). The effects of classroom mathematics teaching on students' learning. In F. K. Lester (Ed.), Second handbook of research on mathematics teaching and learning (pp. 371-404). Charlotte, NC: Information Age Publishing.

Huang, J., Guo, B., Kim, Y., \& Sherraden, M. (2010). Parental income, assets, borrowing constraints and children's post-secondary education. Children and Youth Services Review, 32(4), 585-594.

Ingvarson, L., Beavis, A., Bishop, A., Peck, R., \& Elsworth, G. (2004). Investigation of effective mathematics teaching and learning in Australian secondary schools. Canberra: Australian Government Department of Education, Science and Training.

Itkonen, T., \& Jahnukainen, M. (2007). An analysis of accountability policies in Finland and the United States. International Journal of Disability, Development and Education, 54(1), 523.

Jyrhämä, R., Kynäslahti, H., Krokfors, L., Byman, R., Maaranen, K., Toom, A., \& Kansanen, P. (2008). The appreciation and realisation of research-based teacher education: Finnish students' experiences of teacher education. European Journal of Teacher Education, 31(1), 1 $-16$. 
Karhunen, J., \& Keloharju, M. (2001). Shareownership in Finland 2000. Liiketaloudellinen Aikakauskirja (The Finnish Journal of Business Economics) (2), 188-226.

Keloharju, M., Knupfer, S., \& Rantapuska, E. (2012). Mutual fund and share ownership in Finland. Liiketaloudellinen Aikakauskirja, 2012(2), 178-198.

Kim, Y., \& Sherraden, M. (2011). Do parental assets matter for children's educational attainment?: Evidence from mediation tests. Children and Youth Services Review, 33(6), 969979.

Kivirauma, J. \& Ruoho, K. (2007). Excellence through special education? Lessons from the Finnish school reform. International Review of Education, 53, 283-302.

Kjaernsli, M., \& Molander, B.-O. (2003). Scientific Literacy: Content Knowledge and Process Skills. In S. Lie, P. Linnakylä \& A. Roe (Eds.), Northern Lights on PISA. Unity and Diversity in the Nordic Countries in PISA 2000 (pp. 63-70). Oslo: University of Oslo, Department of teacher education and school development.

Korhonen, J., Linnanmäki, K., \& Aunio, P. (2012). Language and mathematical performance: a comparison of lower secondary school students with different level of mathematical skills. Scandinavian Journal of Educational Research, 56(3), 333-344.

Krokfors, L., Kynäslahti, H., Stenberg, K., Toom, A., Maaranen, K., Jyrhämä, R., Byman, R. \& Kansanen, P. (2011). Investigating Finnish teacher educators' views on research-based teacher education. Teaching Education, 22(1), 1 - 13.

Kupari, P. (2004). Recent developments in Finnish mathematics education. Nordic Studies in Mathematics Education, 9, 7-20.

Kupiainen, S., Hautamäki, J., \& Karjalainen, T. (2009). The Finnish education system and PISA: University of Helsinki and the Ministry of Education, Finland.

Laukkanen, R. (2008). Finnish strategy for high-level education for all. In N. Soguel \& P. Jaccard (Eds.), Governance and performance of education systems (pp. 305-324). Dordrecht: Springer.

Lie, S., Linnakylä, P., \& Roe, A. (2003). Northern lights on PISA. In S. Lie, P. Linnakylä \& A. Roe (Eds.), Northern Lights on PISA: Unity and diversity in the Nordic countries in PISA 2000 (pp. 7-20). Oslo: Department of Teacher Education and School Development, University of Oslo.

Linnakylä, P. (2002). Reading in Finland. In C. Papanastasiou \& V. Froese (Eds.), Reading Literacy in 14 Countries. Lefkosia: University of Cyprus Press.

Martio, O. (2009). Long term effects in learning mathematics in Finland - curriculum changes and calculators. The Teaching of Mathematics, 12(2), 51-56.

McKinsey and Company. (2007). How the world's best-performing school systems come out on top. London: McKinsey and Company.

Mullis, I. V. S., Martin, M. O., Gonzalez, E. J., Gregory, K. D., Garden, R. A., O'Connor, K. M., . . . Smith, T. A. (2000). TIMSS 1999 International mathematics report. Boston: Boston College.

Mullis, I. V. S., Martin, M. O., Foy, P., \& Arora, A. (2012). TIMSS 2011 International Results in Mathematics. Boston: TIMSS \& PIRLS International Study Center, Boston College. 
Niemi, H. (2012). The societal factors contributing to education and schooling in Finland. In H. Niemi, A. Toom \& A. Kallioniemi (Eds.), Miracle of education: The principles and practices of teaching and Learning in Finnish schools (pp. 19-38). Rotterdam: Sense.

Niemi, H., \& Jakku-Sihvonen, R. (2006). Research-based teacher education. In R. JakkuSihvonen \& H. Niemi (Eds.), Research-based teacher education in Finland (pp. 31-50). Turku: Finnish Educational Research Association.

Niemi, E, \& Metsämuuronen, J (2010), Miten Matematiikan Kehittyvät?: Matematiikan oppimistulokset peruskoulun viidennen vuosiluokan jälkeen vuonna 2008. Helsinki: Edita Prima Oy.

Norris, N., Asplund, R., MacDonald, B., Schostak, J. \& Zamorski, B. (1996). An independent evaluation of comprehensive curriculum reform in Finland. Helsinki: National Board of Education.

Organisation for Economic Cooperation and Development. (2003). The PISA 2003 assessment framework: Mathematics, reading, science and problem solving knowledge and skills. Paris: OECD PISA.

Organisation for economic co-operation and development. (2009). PISA 2009 Assessment Framework: Key competencies in reading, mathematics and science. Paris: OECD PISA.

Pehkonen, E. (2009). How Finns learn mathematics: What is the influence of 25 years of research in mathematics education? In M. Lepis (Ed.), Teaching mathematics: Retrospectives and perspectives (pp.71-101). Tallinn University: Institute of Mathematics and Natural Sciences.

Poikolainen, J. (2012). A case study of parents' school choice strategies in a Finnish urban context. European Educational Research Journal, 11(1), 127-144.

Prais, S. J. (2003). Cautions on OECD's recent educational survey. Oxford Review of Education, 29(2), 139-163

Reinikainen, P. (2012). Amazing PISA results in Finnish comprehensive schools. In H. Niemi, A. Toom \& A. Kallioniemi (Eds.), Miracle of education: The principles and practices of teaching and Learning in Finnish schools (pp. 3-18). Rotterdam: Sense.

Ryve, A., Hemmi, K., \& Börjesson, M. (2011). Discourses about school-based mathematics teacher education in Finland and Sweden. Scandinavian Journal of Educational Research, 116.

Sahlberg, P. (2007). Education policies for raising student learning: the Finnish approach. Journal of Education Policy, 22(2), 147-171.

Sahlberg, P. (2011). The fourth way of Finland. Journal of Educational Change, 12(2), 173185.

Savolainen, H. (2009). Responding to diversity and striving for excellence: The case of Finland. Prospects, 39(3), 281-292.

Schleicher, A. (2007). Can competencies assessed by PISA be considered the fundamental school knowledge 15-year-olds should possess? Journal of Educational Change, 8(4), 349357.

Schleicher, A. (2009). Securing quality and equity in education: Lessons from PISA. Prospects, 39(3), 251-263. 
Shiel, G., Perkins, R., Close, S., \& Oldham, E. (2007). PISA mathematics: A teacher's guide. Dublin: Department of Education and Science.

Simola, H. (2005). The Finnish miracle of PISA: Historical and sociological remarks on teaching and teacher education. Comparative Education, 41, 455-470.

Strauss, A., \& Corbin, J. (1998). Basics of qualitative research: techniques and procedures for developing grounded theory. London: Sage.

Tarvainen, K., \& Kivelä, S. K. (2006). Severe shortcomings in Finnish mathematics skills. Matilde, 29, 10.

Toom, A., Kynäslahti, H., Krokfors, L., Jyrhämä, R., Byman, R., Stenberg, K., Maaranen, K., \& Kansanen, P. (2010). Experiences of a research-based approach to teacher education: Suggestions for future policies. European Journal of Education, 45(2), 331-344.

Tramonte, L., \& Willms, J. D. (2010). Cultural capital and its effects on education outcomes. Economics of Education Review, 29(2), 200-213.

Tuovinen, J. (2008). Learning the craft of teaching and learning from world's best practice. The Case of Finland. In D. McInerney \& A. Liem (Eds.), Teaching and learning: International best practice (pp.51- 77). Charlotte, NC: Information Age Publishing.

Välijärvi, J. (2004). The system and how does it work: Some curricular and pedagogical characteristics of the Finnish comprehensive school. Education Journal, 32, 31-55.

Välijärvi, J., Linnakylä, P., Kupari, P., Reinikainen, P. \& Arffman, I. (2002). The Finnish success in PISA - and some reasons behind it. Jyväskylä: Institute for Educational Research, University of Jyväskylä.

Vilenius-Tuohimaa, P. M., Aunola, K., \& Nurmi, J.-E. (2008). The association between mathematical word problems and reading comprehension. Educational Psychology: An International Journal of Experimental Educational Psychology, 28(4), 409-426.

Vislie, L. (2003). From integration to inclusion: focusing global trends and changes in the western European societies. European Journal of Special Needs Education, 18(1), 17-35.

Westbury, I., Hansen, S.-E., Kansanen, P., \& Bjorkvist, O. (2005). Teacher education for research-based practice in expanded roles: Finland's experience. Scandinavian Journal of Educational Research, 49(5), 475-485.

Xu, L., \& Clarke, D. (2013). Meta-rules of discursive practice in mathematics classrooms from Seoul, Shanghai and Tokyo. ZDM - The International Journal on Mathematics Education, In press. doi: 10.1007/s11858-012-0442-x 